International Journal of Agriculture, Environment and Bioresearch

Vol. 4, No. 04; 2019

ISSN: $2456-8643$

\title{
ANTIMICROBIAL ACTIVITIES OF AQUEOUS AND ETHANOLIC EXTRACTS OF TEN SPICES ON THREE CLINICAL BACTERIAL ISOLATES
}

\author{
Bankole, Samuel Opeyemi ${ }^{* 1}$, Akinkugbe, Temilola Ajoke ${ }^{2}$, Adedokun, Samuel Ayotunde and Oyedeji, \\ Marufat Bukola4 \\ ${ }^{1}$ Biomedicinal Research Centre, Forestry Research Institute of Nigeria, Ibadan. \\ ${ }^{2}$ Microbiology department, Federal University of Agriculture Abeokuta. \\ ${ }^{3}$ Basic Science and General Studies Department. Federal College of Forestry, Ibadan. \\ ${ }^{4}$ Vocational Studies Department, Federal College of Forestry, Ibadan
}

http://doi.org/10.35410/IJAEB.2019.4425

\begin{abstract}
In vitro antimicrobial effect of aqueous and ethanolic extract of ten different spices namely; ginger, garlic, cinnamon, turmeric, onions, curry, thyme, lime leaves, bay leaf and red pepper was assessed by disc diffusion method at concentration (100,75, 50 and 25) against three bacterial species: Staphyloccocus aureus, Escherichia coli and Klebsiella pneumoniae. Minimum inhibitory concentration (MIC) was determined by broth dilution method. The most susceptible bacteria were Escherichia coli and Klebsiella pneumoniae. Ethanolic extract of curry and bay leaf did not have any effect on the three isolates while aqueous extracts of ginger, lime and thyme did not have any effect on the bacteria. Aqueous extract of cinnamon showed good inhibitory activity against the three bacterial species with the zone of inhibition between $9-25 \mathrm{~mm}$ followed by turmeric with inhibition zone of $9-17 \mathrm{~mm}$, the extract did not show any effect on Escherichia coli. Garlic-onion aqueous extract showed a compensatory synergistic effect on the three organisms with the zone of inhibition ranging between $9-24 \mathrm{~mm}$. the MIC for aqueous and ethanolic extract of cinnamon was between $3.125 \mathrm{mg} / \mathrm{ml}$ to $12.5 \mathrm{mg} / \mathrm{ml}$ while turmeric has a MIC of $6.25 \mathrm{mg} / \mathrm{ml}$ to $12.5 \mathrm{mg} / \mathrm{ml}$ although the water extract did not have any effect on $\mathrm{K}$. pneumoniae.
\end{abstract}

Keywords: Antimicrobial, Inhibitory, Extract, Bacteria.

\section{INTRODUCTION}

Spices have been defined as plant substances from indigenous or exotic origin, aromatic or with strong taste, used to enhance the taste of foods. Spices include leaves (coriander, mint), flower (clove), bulbs (garlic, onion), fruits (red chili, black pepper), stem (cinnamon), rhizomes (ginger, turmeric) and other plant parts. Spices are very important and useful as therapeutic agent against many pathogenically infections [1]. The spices have a unique aroma and flavour which are derived [2] [3].

The phytochemicals are antimicrobial substances present in the spices which are capable of attracting benefits and repel harmful organisms; they also serve as photo protectants and responds to environmental changes [3]. Numerous classes of phytochemical including the isoflavones, anthocyanins and flavonoids are found associated with the spices [3].Traditionally used as a spice for decades, turmeric as an herbal medicine caught the attention of the modern 
world only recently. It is used in South Asian cooking as well as traditional Chinese and ayurvedic medicine. The active component of turmeric is curcumin, which has antioxidant and anti-inflammatory properties [4]. Cinnamonium zeylanicum (Cinnamon) is one of the oldest known spices. Its medicinal uses have been recorded around $2700 \mathrm{BC}$ and somewhat later in ancient Greek and Latin text. This plant has been used in ayurvedic (Indian traditional medicine) [5]. It has also been used to treat gastrointestinal disturbances, bronchial asthma and asthenia of blood. The British Herbal Pharmacopia indicates its use for flatulent dyspepsia, flatulent colic and diarrhea. The German Standard License for cinnamon bark tea infusion recommends it for a feeling of distention, flatulence, and mild cram-like gastrointestinal disorders due to reduced production of gastric juice.

Spices also fitted into philosophic concepts of improving health, since it was understood that they could affect the four humus (blood, phlegm, yellow blue and black bile) and influence the corresponding moods sanguine, phlegmatic, choleric and melancholic Spices are also used for stabilizing several food items from deterioration [6]. Spices are considered as rich source of bioactive antimicrobial compounds [7]. Spices are also known to have some ethno-medicinal or antimicrobial properties [8].

Antibiotic resistance has become a major clinical and public health problem. We are currently faced with (multi) resistant bacteria that are difficult and sometimes impossible to treat [9]. The tremendous therapeutic advantage afforded by antibiotics is being threatened by the emergence of increasingly resistant strains of microbes. The problem has recently been worsened by the steady increase in multi-resistant strains and by the restriction of antibiotic discovery and development programs [9].

The widespread use of antibiotics both inside and outside of medicine is playing a significant role in the emergence of resistant bacteria [10]. Medicinal plants, that form the backbone of traditional system of medicine, have in the last few decades been the subject of interest for pharmacological studies. This has been brought about by the acknowledgement of the value of medicinal plants as potential source of novel bioactive compounds of therapeutic prominence [11]. Also phytochemicals from the medicinal plants serve as a source of lead compounds in drug discovery and design. It has been pointed out that more than $80 \%$ of world's population depends on plants to meet their primary health care needs [12]. So therefore this study seeks; to investigate the antimicrobial susceptibility profile of ethanolic and aqueous extracts of some selected spices on three bacterial isolates, the minimum inhibitory concentration of the spices extracts and the synergistic effects of the spices of same family against the isolates

\section{MATERIALS AND METHOD}

\subsection{Sample collection}

Ten (10) different spices namely: ginger, garlic ,lime, curry, lime leaves, bay leaf, red pepper and onions, were purchased from the market at Ago-Iwoye while cinnamon and turmeric were purchased a Shoprite, Ibadan. Three bacterial isolates used in the study, among these are two Gram negative, namely, Escherichia coli and Klebsiella sp and one Gram-positive, 
Staphylococcus aureus were collected from Federal Medical Centre, Abeokuta. The bacteria were maintained on nutrient agar slants at $4^{\circ} \mathrm{C}$.

\subsection{Sterilization of glassware}

All glassware used for this research work was washed, rinsed and air dried. They were sterilized in an oven at $160^{\circ} \mathrm{c}$ for one hour. McCartney bottles, water and media in conical flasks were autoclaved at $121^{\circ} \mathrm{c}$ for $15 \mathrm{mins}$. The bench top and work table surfaces were also sterilized with ethanol before work commenced. Inoculating loop were sterilized by flaming over a spirit lamp until it was red hot and then dipped in alcohol to cool before used.

\subsection{Preparation of Spices Extracts}

The spices were dried in hot air oven at $35-40^{\circ} \mathrm{C}$ for 2 to 3 days and were ground using a blender. The powders were weighed and extracted with distilled water and ethanol separately. They were soaked in respective solvents for 3days and then filtered with Whatman filter paper. The filtrate was concentrated and weighed. The respective solvents were added to make final concentration of each of the extracts; the extracts were used for further studies such as antibacterial activity and minimum inhibitory concentration (MIC) [13].

\subsection{Inoculum preparation}

Three or four colonies of bacteria were transferred to the test tube containing $5 \mathrm{ml}$ of sterile nutrient broth. It was incubated at $37^{\circ} \mathrm{C}$ for $4 \mathrm{hrs}$.

\subsection{Evaluation of antibacterial activity of the spices extract}

The extracts of spices were screened for its antimicrobial activity against the organisms by agar well diffusion method of [14]. Sterile cotton swab was dipped in to the prepared inoculums and seeded all over the nutrient agar plate by rotating through an angle of $60^{\circ}$. After each swabbing, the swab was passed round the edges of the agar surface and left to dry for few minutes at room temperature with lid closed. Then with the help of the sterile cork borer $(6 \mathrm{~mm})$, wells were made in the inoculated plate labeled. The different concentrations $(100,75,50$, and 25) $\mathrm{mg} / \mathrm{ml}$ was dispensed in the respective wells with the help of the syringe. The plates were left for half an hour with the lid closed. The plates were incubated at $37^{\circ} \mathrm{C}$ for $24 \mathrm{hr}$ then observed for the zone of inhibition which is suggested by the clear area around the well. The experiment was repeated in triplicates and the zone of inhibition was measured and expressed in millimeters.

\subsection{Minimum Inhibitory Concentration}

The method of [15] was employed but modified a little. Minimum inhibitory concentration of extract was determined by broth dilution method. For broth dilution, about four colonies of the bacteria was inoculated into $5 \mathrm{ml}$ of Nutrient broth. $1 \mathrm{ml}$ was added to each tube containing extracts at various concentrations. The tubes were incubated at $37^{\circ} \mathrm{C}$ for $24 \mathrm{hrs}$ and observed for visible growth after shaking the tubes gently. The experiment was repeated twice. The Minimum Inhibitory Concentration was taken as the lowest concentration of the extracts at which there is turbidity after incubation [15]. 


\subsection{Antimicrobial sensitivity testing}

The cultures were enriched in nutrient broth for $6-8 \mathrm{hrs}$ at $37^{\circ} \mathrm{c}$ using a sterile cotton swab; the cultures were aseptically swabbed on Muller Hilton agar and allowed to dry for 5 mins then, an ethanol dipped and flamed forceps was used to pick the antibiotic disc which was aseptically placed on the seeded surface of the Muller Hilton agar sufficiently separated in other to avoid over lapping. The susceptibility of the bacteria strains to various antibiotics was performed by the following national Committee for clinical laboratory standard Recommendation [16]. The zones of inhibition were recorded after incubating at $37^{\circ} \mathrm{c}$ for $24 \mathrm{hrs}$.

\subsection{Statistical analysis}

All the values of inhibition zone were analyzed using Analyses of Variance (ANOVA). Differences between groups were considered significant at $\mathrm{P}<0.05$ level of significance.

\section{RESULTS}

The Physical characteristics of extracts is represented in table 1

Table 1: The physical characteristics of extracts

\begin{tabular}{|c|c|c|c|c|}
\hline \multirow[t]{2}{*}{ Plant extract } & \multicolumn{3}{|c|}{ Colour of extract } & \multirow[b]{2}{*}{ Smell } \\
\hline & Water extract & Ethanol extract & Texture & \\
\hline Onions & Brown & Light brown & Oily & Spicy \\
\hline Garlic & Light yellow & Yellow & Oily & Spicy \\
\hline Ginger & Light yellow & Yellowish brown & Gummy & Spicy \\
\hline curry & Light yellow & Yellow & oily & Spicy \\
\hline Red pepper & Brick red & Red & oily & Spicy \\
\hline Thyme & Brown & Coffee brown & oily & Spicy \\
\hline Lime & Brown & Deep brown & oily & Spicy \\
\hline Bayleaf & Reddish brown & Dark green & Gummy & Spicy \\
\hline Tumeric & Yellow & Wine & oily & Spicy \\
\hline Cinnamon & Red & Yellowish brown & Oily & Spicy \\
\hline
\end{tabular}


The concentration of different aqueous (water) extract of spices against Escherichia coli is represented in figure 1 below. Ginger, lime leaves, bay leaf, thyme and turmeric shows no antimicrobial effect on E. coli while cinnamon has the highest inhibitory effect on E. coli.

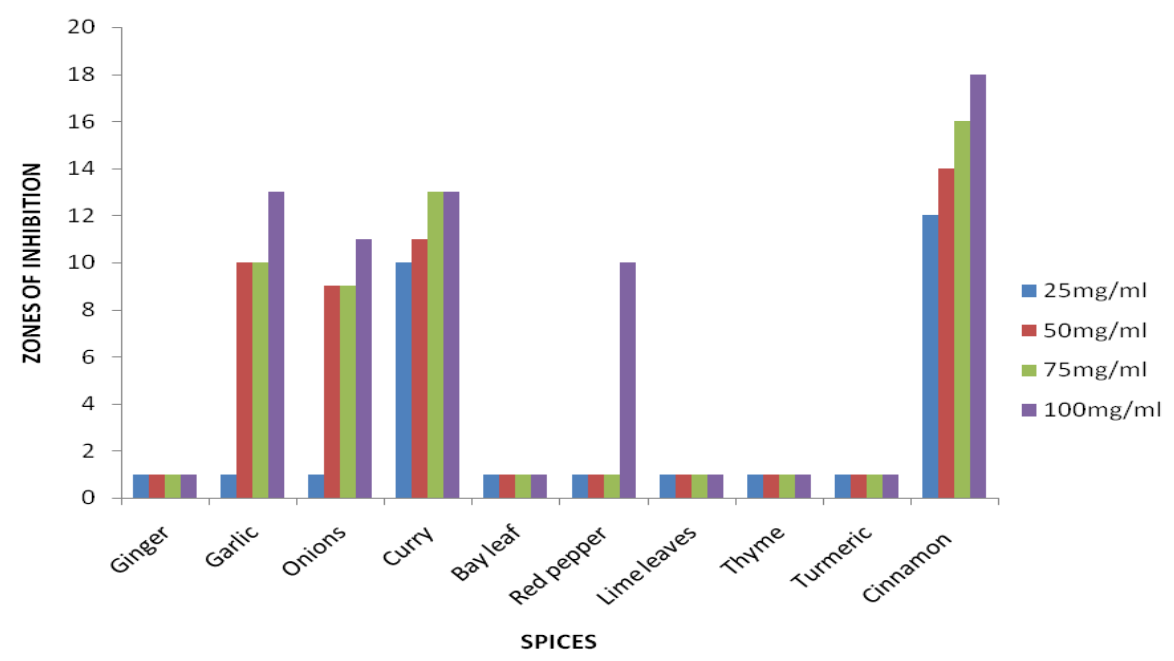

FIGURE 1: Aqueous extract of spices at different concentration against E. coli.

The concentration of different aqueous (water) extract of spices against $S$. aureus is represented in figure 2 below. Onions, turmeric and cinnamon inhibited the growth of $S$. aureus while ginger and garlic do not have any antimicrobial effect.

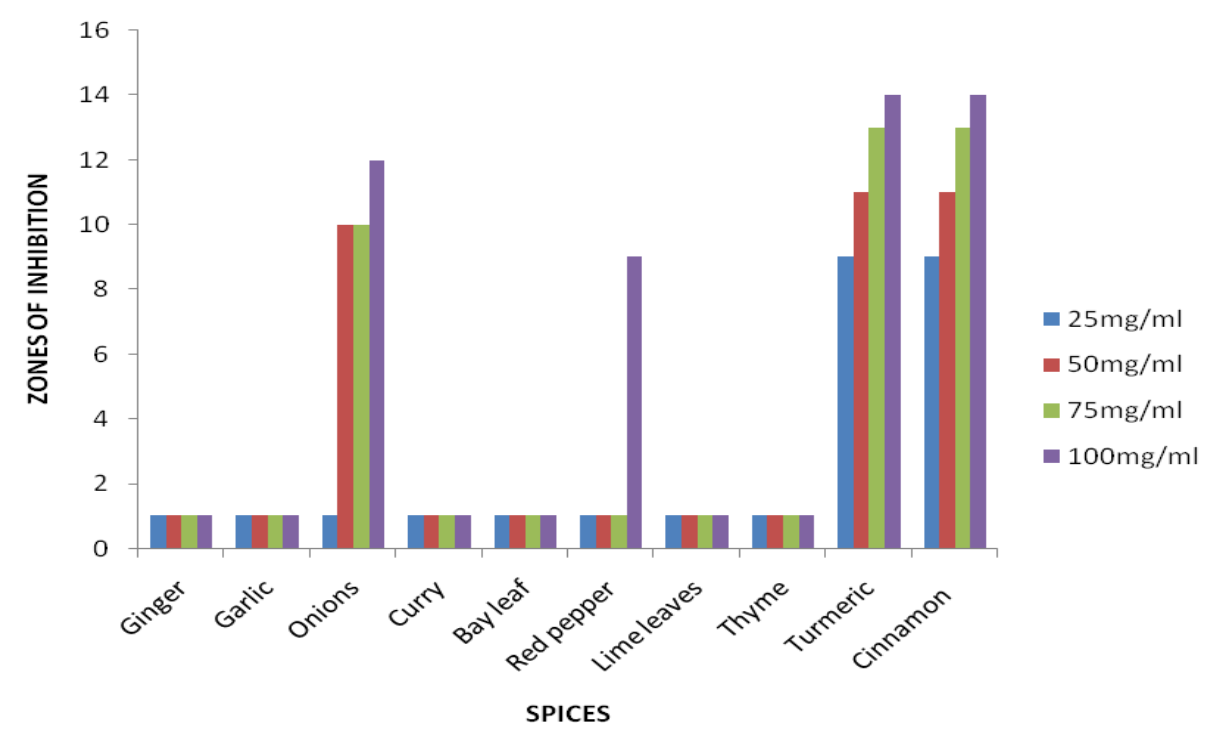

FIGURE 2: Aqueous extract of spices at different concentration against S. aureus. 
The concentration of different aqueous (water) extract of spices against $K$. pneumoniae is represented in figure 3 below. $K$. pneumoniae was sensitive to turmeric but lime leaves and thyme has no inhibitory effect on it.

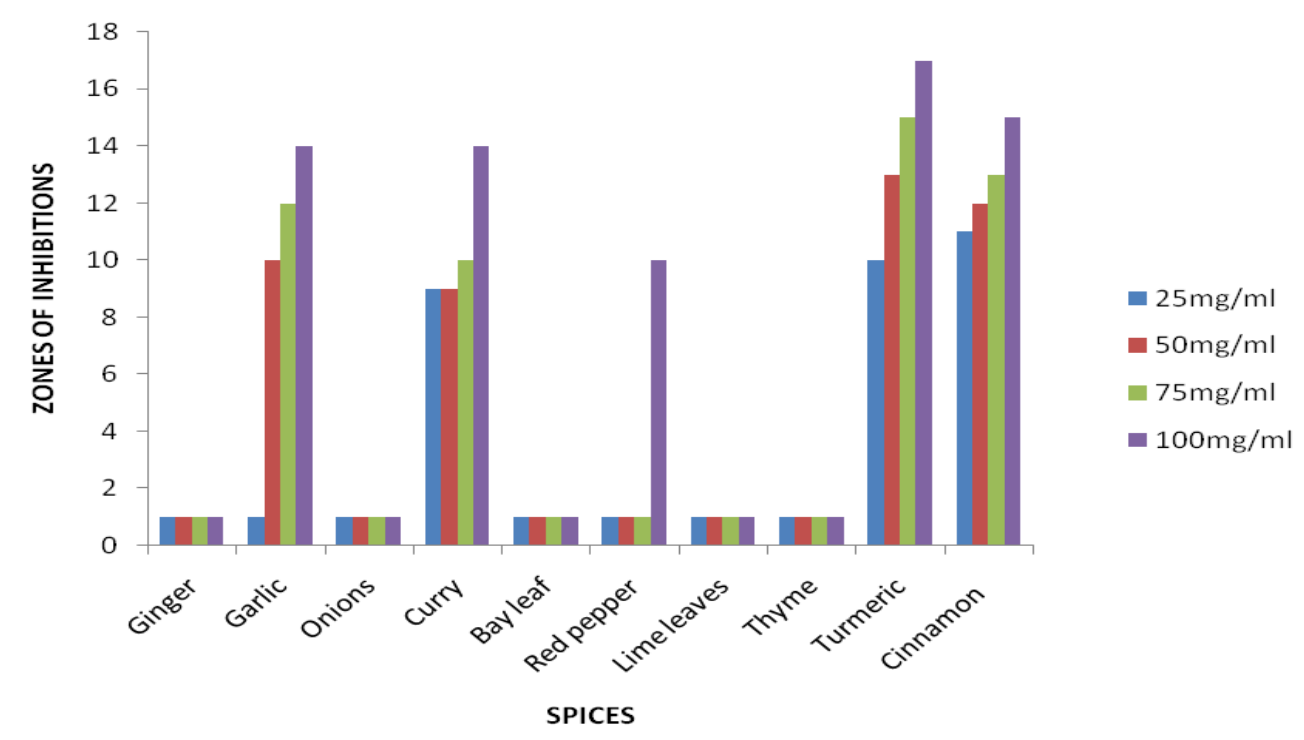

FIGURE 3: Aqueous extract of spices at different concentration against $K$. pneumoniae .

The concentration of different ethanolic extract of spices against $E$. coli is represented in figure 4 below. Cinnamon shows a high inhibitory effect on $E$. coli while curry and bay leaf have no antimicrobial effect on it.

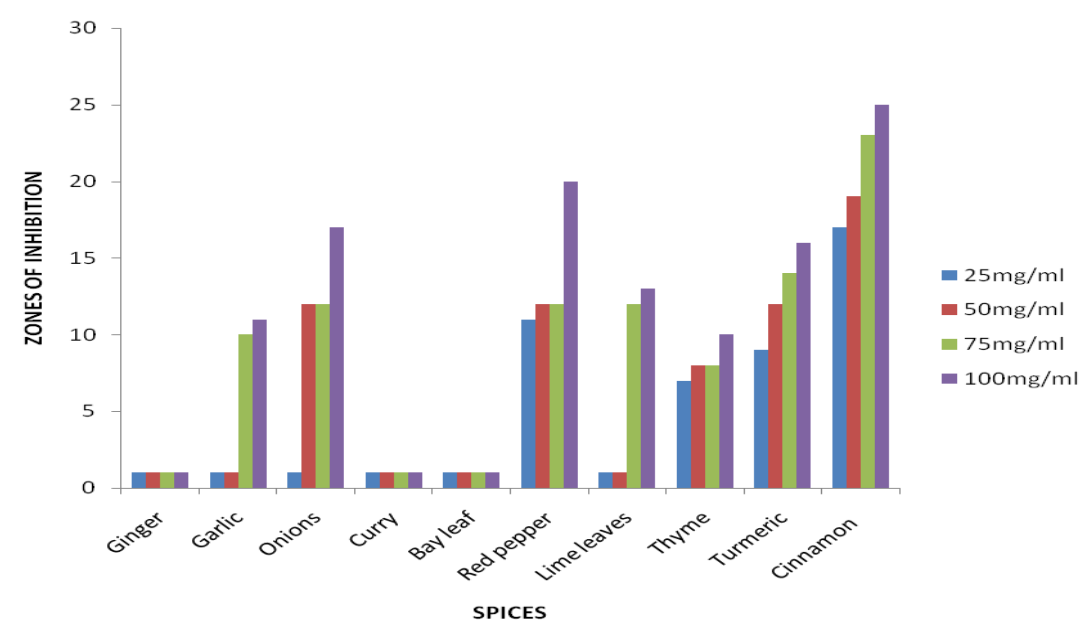

FIGURE 4: Ethanolic extract at different concentration against $E$. coli. 
The concentration of different ethanolic extract of spices against $S$. aureus is represented in figure 5 below. Cinnamon and red pepper showed the highest inhibition zones against $S$. aureus while turmeric and curry have no antimicrobial effect on it.

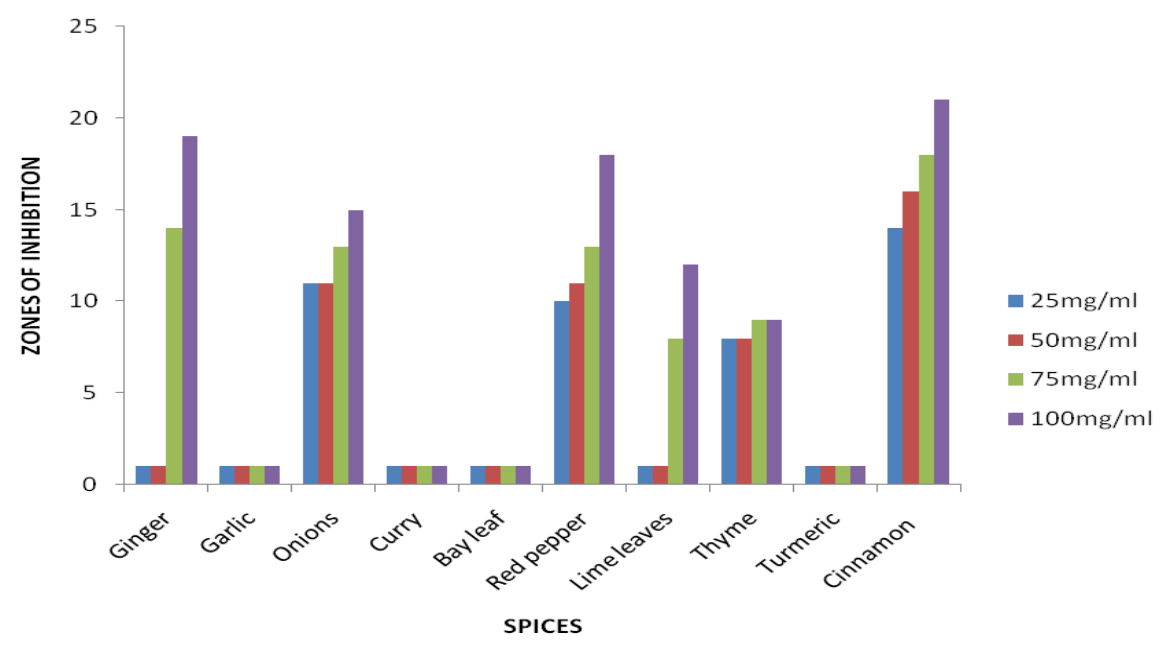

FIGURE 5: Ethanolic extract at different concentration against $S$. aureus.

The concentration of different ethanolic extract of spices against $K$. pneumoniae is represented in figure 6 below. Lime leaves showed a high inhibitory effect on $K$. pneumoniae while curry and bay leaf have no antimicrobial effect on the isolate.

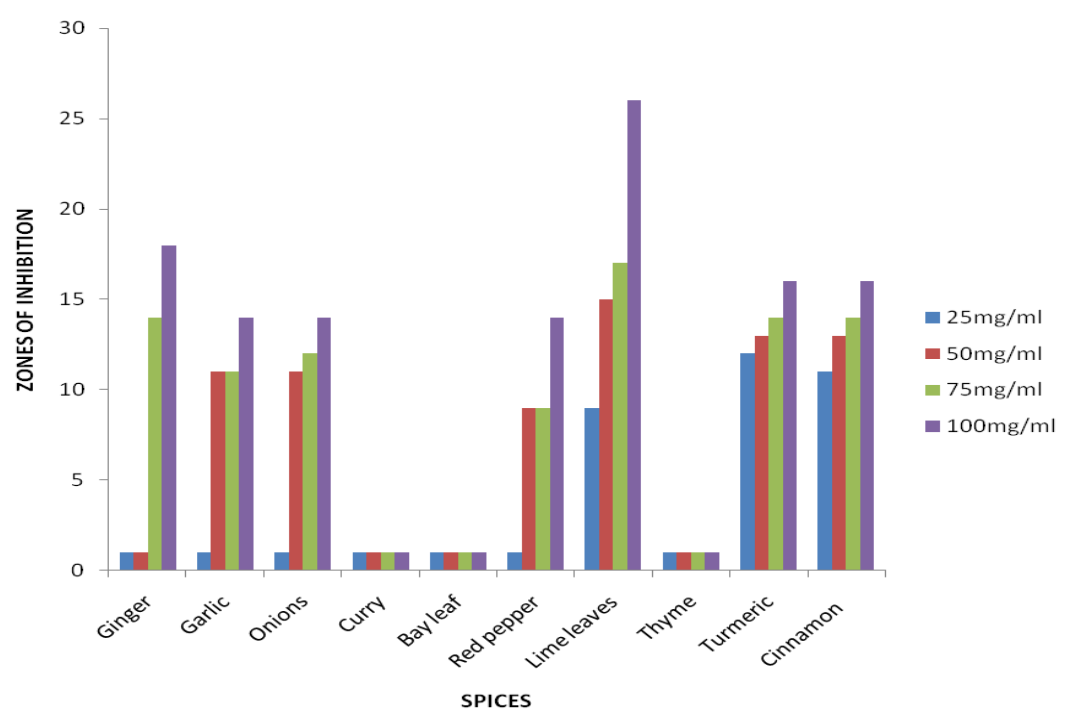

FIGURE 6: Ethanolic extract at different concentration against $K$. pneumoniae. 
The synergistic effect of water extract of spices belonging to the same family at different concentration is represented in table 2 below. Lime - curry have a higher antimicrobial effect against $S$. aureus and $E$. coli while ginger - turmeric does not have any effect on them.

TABLE 2: The synergism of water extract at different concentration against the clinical isolates.

\begin{tabular}{|lccccccccccccc|}
\hline $\begin{array}{l}\text { Spices (Extract } \\
\text { mg/ml) }\end{array}$ & in & \multicolumn{4}{c}{ E. coli } & \multicolumn{4}{c|}{ S. aureus } & \multicolumn{4}{c|}{ k. pneumonia } \\
& & 25 & 50 & 75 & 100 & 25 & 50 & 75 & 100 & 25 & 50 & 75 & 100 \\
\hline Garlic - Onion & 10 & 15 & 16 & 24 & 9 & 10 & 12 & 18 & 10 & 12 & 14 & 18 \\
Lime - Curry & 9 & 10 & 12 & 14 & - & - & 9 & 12 & 8 & 9 & 12 & 14 \\
Ginger - Turmeric & - & - & - & - & - & - & - & - & 11 & 13 & 14 & 17 \\
\hline
\end{tabular}

*Values are means of three replicates.

The synergistic effect of ethanol extract of spices belonging to the same family at different concentration is represented in table 3 below. Ginger - turmeric have a high inhibitory effect against $S$. aureus and $K$. pneumoniae while Lime-curry have no effect on E. coli.

TABLE 3: The synergism of ethanol extract at different concentration against the clinical isolates.

\begin{tabular}{|c|c|c|c|c|c|c|c|c|c|c|c|c|}
\hline \multirow{2}{*}{$\begin{array}{ll}\text { Spice } & \text { (Extract } \\
\mathrm{mg} / \mathrm{ml}) & \end{array}$} & \multicolumn{4}{|c|}{ E. coli } & \multicolumn{4}{|c|}{ S. aureus } & \multicolumn{4}{|c|}{ k. pneumoniae } \\
\hline & 25 & 50 & 75 & 100 & 25 & 50 & 75 & 100 & 25 & 50 & 75 & 100 \\
\hline Garlic - Onion & 9 & 12 & 13 & 14 & - & 8 & 9 & 12 & - & - & 12 & 12 \\
\hline Lime - Curry & - & - & - & - & - & - & 8 & 10 & 9 & 10 & 12 & 15 \\
\hline Ginger - Turmeric & - & 8 & 9 & 9 & 8 & 9 & 10 & 12 & - & - & 9 & 10 \\
\hline
\end{tabular}

*Values are means of three replicates.

The table 4 below shows the Minimum Inhibitory Concentration (MIC) of both water and ethanol extracts. Both water and ethanol extract of cinnamon and turmeric showed the highest minimum inhibitory concentration against the clinical isolates. 
International Journal of Agriculture, Environment and Bioresearch

Vol. 4, No. 04; 2019

ISSN: $2456-8643$

TABLE 4: The Minimum inhibitory concentration of water and ethanol extracts.

\begin{tabular}{|lcccccc|}
\hline Spices & Water extract & \multicolumn{5}{c|}{ Ethanol extract } \\
& K. pneumoniae & S. aureus & E. coli & K.pneumoniae & S. aureus & E.coli \\
\hline Ginger & - & - & - & - & - & - \\
Garlic & - & - & - & - & - & - \\
Onions & - & - & - & - & 25 & - \\
Curry & 25 & - & 25 & - & - & - \\
Bay leaf & - & - & - & - & - & - \\
Red pepper & - & - & - & - & 12.5 & 6.25 \\
Lime leaves & - & - & - & 12.5 & - & - \\
Thyme & - & - & - & - & - & - \\
Turmeric & - & 12.5 & 12.5 & 12.5 & - & 6.25 \\
Cinnamon & 6.25 & 12.5 & 12.5 & 12.5 & 6.25 & 3.125 \\
\hline
\end{tabular}

TABLE 5: Antibiotics Sensitivity of Gram Positive bacteria in (mm)

\begin{tabular}{|l|l|l|l|l|l|l|l|l|}
\hline Antibiotics & CXC & GEN & COT & CHL & AUG & AMX & ERY & TET \\
\hline $\begin{array}{l}\text { Staph } \\
\text { aureus }\end{array}$ & 13 & 11 & 15 & 27 & 26 & 17 & 17 & 13 \\
\hline
\end{tabular}

Key:

Cloxacillin $(5 \mu \mathrm{g})$

Gentamycin $(10 \mu \mathrm{g})$

Cotrimoxazole $(25 \mu \mathrm{g})$

Chloramphenicol $(10 \mu \mathrm{g})$

Augmentin $(30 \mu \mathrm{g})$

Amoxicillin $(30 \mu \mathrm{g})$ 
Erythromycin $(5 \mu \mathrm{g})$

Tetracycline $(10 \mu \mathrm{g})$

Table 6: Antibiotics Sensitivity testing of Gram Negative bacteria in ( $\mathbf{m m})$

\begin{tabular}{|l|l|l|l|l|l|l|l|l|}
\hline Antibiotics & NIT & GEN & NAL & OFL & AUG & TET & AMX & COT \\
\hline E coli & 31 & 30 & - & 38 & - & - & - & 17 \\
\hline $\begin{array}{l}\text { Kleb } \\
\text { pneumoniae }\end{array}$ & 22 & 17 & 22 & 31 & - & 17 & - & 22 \\
\hline
\end{tabular}

Key:

Nitrofuratoin $(30 \mu \mathrm{g})$

Gentamycin $(10 \mu \mathrm{g})$

Naldixic $(30 \mu \mathrm{g})$

Ofloxacin $(30 \mu \mathrm{g})$

Augmentin $(30 \mu \mathrm{g})$

Tetracycline $(10 \mu \mathrm{g})$

Amoxicillin $(30 \mu \mathrm{g})$

Cotrimoxazole $(25 \mu \mathrm{g})$

\section{DISCUSSION AND CONCLUSION}

Spices have since ancient times been an important group of agricultural commodities being used by many civilization all over the World adding flavor and nutritional values to a wide variety of food. However such spices are no longer used for only their culinary effects [17].

The present study was aimed at investigating the potential of ten extensively used Culinary spices commonly known as turmeric, cinnamon, garlic, ginger, bay leaf, lime leaves, curry, thyme, onion and red pepper as effective antimicrobial agents that could possibly contribute to the "natural antibiotic system." Three clinical bacterial isolates microbial species namely: Staphlococcus aureus, Escherichia coli and Klebsiella pneumoniae.

Ethanolic extract of turmeric did not have any effect on $S$. aureus while it has a good inhibitory effect on $K$. pneumoniae with zones of inhibition between $12 \mathrm{~mm}-16 \mathrm{~mm}$ (figure 6). The E. coli was resistant to aqueous extract of turmeric with zone of inhibition between $10 \mathrm{~mm}-17 \mathrm{~mm}$ 
(figure 4). This is not similar to the findings of [18] who reported that the aqueous and ethanolic extract of turmeric was effective against E. coli, Bacillus subtilis and S. aureus and suggested that the activity is due to the presence of curcuminiod, a phenolic compound.The three bacterial isolates were resistant to the aqueous extract of ginger (figure 1-3) while the ethanolic extract inhibited S.aureus and K. pneumoniae with zones of inhibition $14 \mathrm{~mm}-19 \mathrm{~mm}$ (figure 6). E. coli was completely resistance to all extracts of ginger (figure 4). This result compared well to the work of [19] and [20] who reported that the antimicrobial activity of ginger against S. aureus, Candida albicans and Salmonella spp. He said that the antimicrobial activity of ginger may be attributed to the fact that it contains antimicrobial substance such as Zingiberol, Zingiberine and bisabolene [21].The ethanolic extract of cinnamon has the highest inhibitory concentration against the three bacterial clinical isolates whereby $E$. coli was the most susceptible among the strain with zones of inhibition $9 \mathrm{~mm}-25 \mathrm{~mm}$ (figure 4). The aqueous extract also inhibited the whole strain but not as effective as the ethanolic extract with zones of inhibition 9-15mm (figure 1-3). This result was in comparism with the result of [22] whereby cinnamon was effective against the micro organism tested. Aqueous extract of cinnamon showed a MIC ranging from $6.25 \mathrm{mg} / \mathrm{ml}-12.5 \mathrm{mg} / \mathrm{ml}$ for $E$. coli, $6.25 \mathrm{mg} / \mathrm{ml}$ for $S$. aureus and $12.5 \mathrm{mg} / \mathrm{ml}$ for $K$. pneumoniae (table 4).

Ethanolic extract of curry showed no activity against the three bacterial clinical isolates (figure 4-6) and this is in contrast with the findings of [23] who showed that ethanolic extract of curry exhibited inhibition zones of $10-12 \mathrm{~mm}$ at $50 \mathrm{mg} / \mathrm{ml}$ concentration against $S$. aureus and E. coli respectively. Aqueous extract of curry showed inhibition zones ranging from 10-13mm on $E$. coli (figure 1), 9-14mm on $K$. pneumoniae (figure 6) and no activity against on $S$. aureus (figure 2). This result compared well with the study of [15], which tested against seven bacterial isolate and showed that the aqueous extract showed no activity against $S$. aureus.

Ethanolic extract of lime leaves showed effect against the three bacterial isolate. Lime showed the highest inhibitory zone against Klebsiella pneumoniae with zone of 9-26mm (figure 6) it has lesser inhibitory concentration against $E$. coli and $S$. aureus (figure 4-5) has less inhibitory effect against lime ethanolic extract and this result is in comparism with the work of [24] who reported the antibacterial effect of lime leaves on $S$. aureus has mild inhibitory effect ranging from $8-9 \mathrm{~mm}$ but $K$. pneumoniae was $17-22 \mathrm{~mm}$. Lime aqueous extract showed no inhibition against the three bacterial isolates (figure 1-3). The ethanolic extract of red pepper showed inhibition against $S$. aureus, $K$. pneumoniae and E. coli (figure 4-6) with the MIC ranging from $6.25 \mathrm{mg} / \mathrm{ml}$ and $12.5 \mathrm{mg} / \mathrm{ml}$ (table 4). This is in contrast with the work of [22]. which reported no antibacterial activity for. K. pneumoniae. He suggested that different climatic conditions of where plants are grown and different extraction methods resulted in the differences between the antimicrobial activities [22]. Both the aqueous and ethanolic extract of bay leaf showed no activity against the three bacterial isolates (figure $1-6$ ). This result is in contrast with the findings of [25] who showed that aqueous bay leaf extract inhibited $S$. aureus with $12 \mathrm{~mm}$ zone of inhibition at $50 \mathrm{mg} / \mathrm{ml}$ concentration. 
The aqueous and ethanolic extract of garlic showed a high level of inhibition against $E$. coli and $K$. pneumoniae ranging from $10 \mathrm{~mm}-14 \mathrm{~mm}$ (figure4 and 6) without any activity $S$. aureus at all concentrations (figure 1). The ethanolic extract has mild inhibition compared to the aqueous extract. This result is similar to the findings of [26] that showed that the antibacterial activity of ethanol extract was mild compared to the aqueous extract and that there was no inhibition of garlic on $S$. aureus. Ethanolic onion extract showed antimicrobial activity against E. coli, $S$. aureus and $K$. pneumoniae with zones of inhibition ranging from $11 \mathrm{~mm}-17 \mathrm{~mm}$ (figure 4-6). Aqueous extract showed no activity against $K$. pneumoniae and it was less sensitive against $E$. coli $9 \mathrm{~mm}-11 \mathrm{~mm}$ (figure 4 ) and $S$. aureus $10 \mathrm{~mm}-12 \mathrm{~mm}$ (figure 2). This result is in contrast to the work of [27], which showed that onion extracts has higher inhibitory concentration for aqueous extract than ethanol. The results obtained from onion aqueous extract was similar with the observation of [28], who reported moderate antibacterial activity of onion extract against the three bacterial clinical isolates.

Aqueous extract of thyme has no antimicrobial activity against the three bacterial clinical isolates (figure 1-3) while E. coli and S. aureus were less sensitive to the ethanolic extract but no effect on K. pneumoniae (figure 6). This result was similar to [29] which revealed that thyme extract showed high inhibitory effect against E. coli, S. aureus and Pseudomonas aeruginosa. It was known that thymol and carvacol, two major components of thyme extract are both effective against E. coli.

Synergism is the interaction of two or more agents to produce a combined effect greater (Compensatory synergism) than the sum of their separate effects (Antagonistic synergism). According to [30] synergistic activity suggests different mode of actions of the combining while no combinations showed antagonistic effect. [31]. In this study, the spices that belong to the same family was combined together to determine their antimicrobial effect.

Garlic and onion ethanol extracts exhibited inhibition zones ranging from 9mm-14mm (Table 3) against the three clinical bacterial isolates. This inhibition zones are lowered compared to $11 \mathrm{~mm}-$ $17 \mathrm{~mm}$ (figure 4-6) reported for ethanol extract of onion and $11 \mathrm{~mm}-14 \mathrm{~mm}$ (figure 4-6) for garlic (Antagonistic synergism).

Garlic and onion aqueous extract showed strong inhibition zone of 10mm-24mm (table 2) against the three bacterial isolates which is higher than the inhibition zones reported for the individual garlic and onion aqueous extracts (Compensatory synergism).

Lime and curry ethanolic extracts showed a mild inhibition zone of (8mm-10mm) against $S$. aureus and $9 \mathrm{~mm}-15 \mathrm{~mm}$ (table 3 ) against $K$. pneumoniae with no activity for $E$. coli (Antagonistic synergism). This inhibition zone is lowered compared to ethanol extract of lime which have an inhibition zone of $8 \mathrm{~mm}-19 \mathrm{~mm}$ (figure 4-6) on the three bacterial isolates although curry ethanolic extract have no activity on the three clinical bacterial isolates. Lime and curry aqueous showed an inhibition zone of $9 \mathrm{~mm}-14 \mathrm{~mm}$ (table 2) (Antagonistic synergism) against the three bacterial isolates. 
Ginger and turmeric ethanolic extract showed inhibition zone of $8 \mathrm{~mm}-12 \mathrm{~mm}$ (table 3) against the three clinical bacterial isolates. These results are not significant when compared to $14 \mathrm{~mm}$ $19 \mathrm{~mm}$ and $9 \mathrm{~mm}-16 \mathrm{~mm}$ (figure 4-6) inhibition zones reported for ginger and turmeric respectively (Antagonistic synergism).

Ginger and turmeric aqueous extract showed inhibition zone of $11 \mathrm{~mm}-17 \mathrm{~mm}$ against $K$. pneumoniae and no activity against $E$. coli and $S$. aureus (table 2).

The mean difference between the spices used were significant on Escherichia coli and Staphlococcus aureus but was insignificant on Klebsiella pneumonia at $(\mathrm{p}<0.05)$ significant level

\subsection{Antibiotic susceptibility pattern of test strains}

S. aureus was highly susceptible to Augmentin and Chloramphenicol with $26 \mathrm{~mm}$ and $27 \mathrm{~mm}$ zones of inhibition while resistant to Gentamicin (table 5). This conforms to the findings of [32] who reported similar result.

E. coli was sensitive to Ofloxacin and Nitrofuratoin while $K$. pneumoniae was intermediate to Ofloxacin but resistant to Nitrofurantoin. This conforms to the study of [32] who reported that $E$. coli and $K$. pneumoniae were sensitive and intermediate to Ofloxacin respectively while they were both resistant to Augmentin and Amoxicillin.

\section{CONCLUSION}

Spices are food additives, purposely with unique aromatic and flavours, it has been found to be therapeutic [1]. The result of the study emphasizes the usefulness of spices in the treatment of diseases and the need to enhance its exploitation on this regard. This is particularly of urgent interest when the growth rate of multi-resistant drug strains of bacteria worldwide is considered [33]. The results of present study have provided the justification for therapeutic potential of spices. The practice of using spices as supplementary or alternative medicine in developing countries like Nigeria will not reduce only the clinical burden of drug resistance development but also the side effects and cost of the treatment with allopathic medicine [34]. This study also showed that spices extracts possess difference antibacterial activities, most spices only serve as nutritive or nutrient supplement, as flavours, aroma, but rarely serve as antibiotics.

\section{REFERENCES}

[1]. Gull, I., Saeed, M., Shaukat, H., Aslam, S.M., Samara, Z.Q. and Athar, A.M. (2012). Inhibitory effect of Allium sativum and Zinigiber officinale exstracts on clinically important drug resistant pathogenic bacteria. Ann Clin Microbiol Antimicrob. 11(8):1186-1476.

[2]. Avato, P., Tursil, E., Vitali, C., Miccolis, V. and Caddido, V. (2000). Allyl Suffide constituents of garlic volatile oil as antimicrobial agents. Phytomedicine 7:239-243. 
[3]. Melvin, M.J., Jayachitta, J. and Vijayapriya, M. (2009). Antimicrobial activity of some common spices against certain human pathogens. Journal of Medicinal plants Research, 3(11):1134-1136..

[4]. Uma, S. (2012)Turmeric: A Wonder Spice Available at http://nut.bz/3m0sdok3/

[5]. Bonjar, S. (2004). Evaluation of antibacterial properties of some medicinal plants used in Iran. Journal of Ethnopharmacology 94:301-305.

[6]. Kizil, S. and Sogut, T. (2003). Investigation of antibacterial effects of spices. Crop Research. 3:86-90.

[7]. Lia, P. and Roy, J. (2004). Antimicrobial and chemopreventive properties of herbs and spices Current Medical chemistry. 47(2):234-238.

[8]. Singh, G., Kapoor, I.P., Pandey, S.K., Singh, U.K. and Singh, R.K.(2002). Studies on essential oils: part 10; antibacterial activity of volatile oils of some spices. Phytother Res, 16:680-682.

[9]. Levy, S. (2002). The antibiotic paradox, $2^{\text {nd }}$ edn.persus publishing USA.

[10]. Bacon, D., Alm, A., Burr, H., Hu, L., Kopecko, J., Ewing, P., Trust, J. and Gurry, P. (2000). Involvement of a plasmid in virulence of Campylobacter jejuni Pg 81-176.

[11]. Prusti, A., Mishea, S., Sahoo, S. and Mishea, S. (2008). Antibacterial activity of some Indian medicinal plants. Ethanobotanical leaflets. 12:227-228. .

[12]. WHO. (2005): Traditional medicine. Report, EB111/9, World Health Organization, Genevas.

[13]. Sharma, R., Chapagain, B. and Pai, C. (2013). In vitro antibacterial activity of seven spices against clinical isolates of enterococci. Res. Art. Pharm. Sci. 3(1):298-304.

[14]. Lyudmila, B., Sirigan, D., Radka, K., Nikolai, K., Galma, G., Ivan, M., Rossen, N. and Zacharii,K. (2003). Inhibition of Helicobacter pylon growth in vitro Bulgarian propolis. Preliminary report. Journal of Medical microbiology 52: 417-419.

[15]. Manvi, M. and Renu, S. (2004). Antimicrobial efficacy of Murraya koenigii (Linn) spreng root extracts. Indian journal of natural products and resources. 2(1):44-51.

[16]. NCCLS (2006). Performance standard for antimicrobial disc susceptibility Tests: Approved standards, NCCLS documents, M2-13. Villanova, P.A

[17]. Notermans S. and Hoogenboon-Verdgaal A. (1992). Existing and emerging foodborne Diseases. International Journal of Food Microbiology, 15:197-205.

[18]. Chandrana, H., Baluja, S. and Chanda, S. V.(2005). Cokmparison of antibacterial activities of selected species of Zingiberaceae family and some synthetic compounds, Turk. J. Biol. 29: 8397.

[19]. Patmanaj. (2000). Drug delivery. J. Nucl.Med.7:91-95. 
[20]. Indu, M.N., Hatha, A.M., Abirosh, C., Harsha, U. and Vivekanandan, G. (2006). Antimicrobial activityn of some of the South Indian spices against serotypes of Escherichia coli, Listeria monocytogenes and Aeromonas hydrophila, Braz J. Microbiol.37:153-15

[21]. Derrida, M. (1999). Common spices protect bacteria during irradiation 1999. Amj. Chem. Soc. 2: 270-275.

[22]. Agaolu, S., Dostbil, N. and Alemdar, S. (2006). Antimicrobial activity of some spices used in meat industry. Sci. Eng.S. firat.Uni. 18:471-478.

[23]. Manisha, V., Harmeet, S. and Satish, S. (2011). Phytochemical screening and antimicrobial activity of roots of murraya koenigii (linn.) spreng. (rutaceae). Braz..J. Microbiol.42:451455.

[24]. Mandal, S., Debmandal, M., Saha, K. and Pal, N.K. (2000). In Vitro Antibaterial Activity of three Indian Spices against Methicillin-Resistant Staphylococcus aureus. Oman. Med .J. 26(5):319-323.

[25]. Luma, M. (2011). The antibacterial activity of aqueous extract of pepper mint and bay leaf against Staphylococcus aureus. J. Bagh Coll Dentistry. 23(2):146-150.

[26]. Safithri, M., Bintang, M. and Poeloengan, M. (2011). Antibacterial activity of garlic extract against some pathogenic animal bacteria. Journal of Medical Research. 155:20874634.

[27]. Ellmore, G. S. and Feldberg, R. S. (1994). Allin lyase localization in bundle sheaths of the garlic clove (Allium sativum). American Journal of Botany, 81(1): 89-94.

[28]. Srinivasan, D., Nathan, S., Suresh, T. and Perumalsamy, P. (2001). Antimicrobial activities of certain Indian medicinal plants used in folkloric medicine $J$. Ethnopharmacol. 74(3):211-220.

[29]. Sagdic, O., Karahan, A. G., Ozcan, M. and Ozkan, G. (2003). Effect of some spice extracts on bacterial inhibition. Food Science and Technology International. 9(5): 353358.

[30]. Cain, C. C., Lee, D., Waldo III, R. H., Henry, A. T., Casida Jr, E. J., Wani, M. C., Wall, M. E., Oberlies, N. H. and Falkinham III, J. O.(2003). Synergistic antimicrobial activity of metabolites produced by a nonobligate bacterial predator. Antimicrobial Agents and Chemotherapy 47(7): 2113-2117.

[31]. Toroglu, S. (2011). In vitro antimicrobial activity and synergistic/antagonistic effect of interactions between antibiotics and some spice essential oils. Journal of Environmental Biology. 32(1): 23-29.

[32]. Aboaba, O.O. and Efuwape, B.M. (2001). Antibacterial properties of some Nigeria spices.Bio. Res. Comm., 13:183-188.

[33]. Prescott, L. M., Harley, J. P. and Donald, A. K. (2005). Microbiology. 6th ed. McGrawHill Inc., New York, USA. Pp 783. 
34]. Benavides, G.A., Squadrito, G.L., Mills, R.W., Patel, H.D., Isbell, T.S., Patel, R.P., Darley-Usmar V.M., Doeller, J.E. and Kraus, D.W. (2007). Hydrogen sulfide mediates the vasoactivity of garlic. PNAS.104:17977-17982.

\section{APPENDIX}

\section{Media composition}

Table 7: Composition of nutrient agar.

\begin{tabular}{|l|l|}
\hline Nutrient Agar & Gram $(\mathbf{g})$ \\
\hline Beef Extract & 15.0 \\
\hline Peptic digest & 5.0 \\
\hline Yeast extract & 12.0 \\
\hline Sodium chloride & 8.0 \\
\hline $\begin{array}{l}\text { Agar dissolved in } 100 \mathrm{ml} \mathrm{of} \mathrm{distilled} \\
\text { water }\end{array}$ & 15.0 \\
\hline
\end{tabular}

Table 8 :Showing the Analysis of Variance (ANOVA) of ethanol extracts of on the Bacterial species

\begin{tabular}{|ll|l|l|l|l|l|}
\hline & & $\begin{array}{l}\text { Sum } \\
\text { Squares }\end{array}$ & Df & Mean Square & F & Sig. \\
\hline Escherichia coli & Between Groups & 584.833 & 3 & 194.944 & 6.463 & .001 \\
& Within Groups & 2775.167 & 92 & 30.165 & & \\
& Total & 3360.000 & 95 & & & \\
\hline Staphylococcus & Between Groups & 441.083 & 3 & 147.028 & 3.795 & .013
\end{tabular}


International Journal of Agriculture, Environment and Bioresearch

Vol. 4, No. 04; 2019

ISSN: $2456-8643$

\begin{tabular}{|ll|l|l|l|l|l|}
\hline aureus & Within Groups & 3564.250 & 92 & 38.742 & & \\
& Total & 4005.333 & 95 & & & \\
\hline $\begin{array}{llllll}\text { Klebsiella } \\
\text { pneumoniae }\end{array}$ & Between Groups & 22979.708 & 3 & 7659.903 & .717 & .544 \\
& Within Groups & 983155.250 & 92 & 10686.470 & & \\
& Total & 1006134.958 & 95 & & & \\
& & & & & & \\
\hline
\end{tabular}

Table 9: Showing the Analysis of Variance (ANOVA) of aqueous extracts of on the bacterial species

\begin{tabular}{|c|c|c|c|c|c|c|}
\hline & & $\left|\begin{array}{ll}\text { Sum } & \text { of } \\
\text { Squares } & \end{array}\right|$ & Df & Mean Square & $\mathrm{F}$ & Sig. \\
\hline Escherichia coli & $\begin{array}{l}\text { Between Groups } \\
\text { Within Groups } \\
\text { Total }\end{array}$ & $\begin{array}{l}1990.167 \\
1369.833 \\
3360.000\end{array}$ & $\begin{array}{l}7 \\
88 \\
95\end{array}$ & $\begin{array}{l}284.310 \\
15.566\end{array}$ & 18.264 & .000 \\
\hline $\begin{array}{l}\text { Staphylococcus } \\
\text { aureus }\end{array}$ & $\begin{array}{l}\text { Between Groups } \\
\text { Within Groups } \\
\text { Total }\end{array}$ & $\begin{array}{l}2641.333 \\
1364.000 \\
4005.333\end{array}$ & $\begin{array}{l}7 \\
88 \\
95\end{array}$ & $\begin{array}{l}377.333 \\
15.500\end{array}$ & 24.344 & .000 \\
\hline Klebsiella pneumonia & $\begin{array}{l}\text { Between Groups } \\
\text { Within Groups } \\
\text { Total }\end{array}$ & $\begin{array}{l}87531.458 \\
918603.500 \\
1006134.958\end{array}$ & $\begin{array}{l}7 \\
88 \\
95\end{array}$ & $\begin{array}{l}12504.494 \\
10438.676\end{array}$ & 1.198 & .312 \\
\hline
\end{tabular}


Table 10: Showing the Analysis of Variance (ANOVA) of the synergism of ethanol extracts of on the bacterial species

\section{ANOVA}

\begin{tabular}{|ll|l|l|l|l|l|}
\hline & & $\begin{array}{l}\text { Sum } \\
\text { Squares }\end{array}$ & Df & Mean Square & F & Sig. \\
\hline Escherichia coli & Between Groups & 1492.167 & 2 & 746.083 & 68.044 & .000 \\
& Within Groups & 361.833 & 33 & 10.965 & & \\
& Total & 1854.000 & 35 & & & \\
\hline $\begin{array}{lllll}\text { Staphylococcus } \\
\text { aureus }\end{array}$ & Between Groups & 776.056 & 2 & 388.028 & 25.653 & .000 \\
& Within Groups & 499.167 & 33 & 15.126 & & \\
& Total & 1275.222 & 35 & & & \\
\hline Klebsiella pneumonia & Between Groups & 43.056 & 2 & 21.528 & 2.428 & .104 \\
& Within Groups & 292.583 & 33 & 8.866 & & \\
& Total & 335.639 & 35 & & & \\
\hline
\end{tabular}

Table 11: Showing the Analysis of Variance (ANOVA) of the synergism of aqueous extracts of on the bacterial species

\section{ANOVA}

\begin{tabular}{|ll|l|l|l|l|l|}
\hline & & $\begin{array}{l}\text { Sum of } \\
\text { Squares }\end{array}$ & df & Mean Square & F & Sig. \\
\hline Escherichia coli & Between Groups & 212.750 & 3 & 70.917 & 2.567 & .072 \\
& Within Groups & 884.000 & 32 & 27.625 & & \\
& Total & 1096.750 & 35 & & & \\
\hline
\end{tabular}


International Journal of Agriculture, Environment and Bioresearch

Vol. 4, No. 04; 2019

ISSN: 2456-8643

\begin{tabular}{|ll|l|l|l|l|l|}
\hline $\begin{array}{l}\text { Staphylococcus } \\
\text { aureus }\end{array}$ & Between Groups & 714.889 & 3 & 238.296 & 39.307 & .000 \\
& Within Groups & 194.000 & 32 & 6.063 & & \\
& Total & 908.889 & 35 & & & \\
\hline Klebsiella pneumonia & Between Groups & 712.083 & 3 & 237.361 & 17.474 & .000 \\
& Within Groups & 434.667 & 32 & 13.583 & & \\
& Total & 1146.750 & 35 & & & \\
\hline
\end{tabular}

Table 12: Aqueous extract at different concentration against the bacterial clinical isolates.

\begin{tabular}{|lccccccccccccc|}
\hline Spices & \multicolumn{3}{c}{ E. coli } & \multicolumn{4}{c}{ S. aureus } & \multicolumn{3}{c|}{ k. pneumonia } \\
\hline & 25 & 50 & 75 & 100 & 25 & 50 & 75 & 100 & 25 & 50 & 75 & 100 \\
\hline Ginger & - & - & - & - & - & - & - & - & - & - & - & - \\
Garlic & - & 10 & 10 & 13 & - & - & - & - & - & 10 & 12 & 14 \\
Onions & - & 08 & 08 & 11 & - & 10 & 10 & 12 & - & - & - & - \\
Curry & 10 & 11 & 13 & 13 & - & - & - & - & - & - & - & - \\
Bay leaf & - & - & - & - & - & - & - & - & - & - & - & - \\
Red pepper & - & - & - & - & - & - & - & - & - & - & - & - \\
Lime & - & - & - & - & - & - & - & - & - & - & - & - \\
Thyme & - & - & - & - & - & - & - & - & 10 & 13 & 15 & 17 \\
Turmeric & - & - & - & - & 09 & 11 & 18 & 14 & 11 & 12 & 13 & 15 \\
Cinnamon & 12 & 14 & 16 & 18 & 09 & 11 & 13 & 14 & & & \\
\hline
\end{tabular}


International Journal of Agriculture, Environment and Bioresearch

Vol. 4, No. 04; 2019

ISSN: $2456-8643$

Table 13: Aqueous extract at different concentration against the bacterial clinical isolates.

\begin{tabular}{|c|c|c|c|c|c|c|c|c|c|c|c|c|}
\hline Spices & & & coli & & & & aurs & & & $k \cdot p$ & eum & \\
\hline & 25 & 50 & 75 & 100 & 25 & 50 & 75 & 100 & 25 & 50 & 75 & 100 \\
\hline Ginger & - & - & - & - & - & - & 14 & 19 & - & - & 14 & 18 \\
\hline Garlic & - & - & 10 & 11 & - & - & - & - & - & 10 & 11 & 14 \\
\hline Onions & - & 12 & 12 & 17 & 11 & 11 & 13 & 15 & - & $\begin{array}{l}11 \\
-\end{array}$ & $\begin{array}{l}12 \\
-\end{array}$ & $\begin{array}{c}14 \\
-\end{array}$ \\
\hline Curry & - & - & - & - & - & 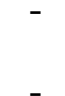 & - & & - & - & - & - \\
\hline & - & - & - & - & 10 & 11 & 13 & 18 & - & 09 & 09 & 14 \\
\hline Red pepper & 11 & 12 & 12 & 20 & & & 08 & 12 & 09 & 15 & 17 & 09 \\
\hline $\begin{array}{l}\text { Lime } \\
\text { Thyme }\end{array}$ & 07 & 08 & 08 & 10 & 08 & 08 & 09 & 09 & $\begin{array}{l}- \\
12\end{array}$ & 13 & 14 & 16 \\
\hline Turmeric & 09 & 12 & 14 & 16 & 14 & 16 & 18 & 21 & 11 & 13 & 14 & 16 \\
\hline Cinnamon & 17 & 19 & 23 & 25 & & & & & & & & \\
\hline
\end{tabular}

